\title{
Lactate and $\mathrm{pH}$ in faeces from patients with colonic adenomas or cancer
}

\author{
H Hove, M Rye Clausen, P Brøbech Mortensen
}

\begin{abstract}
Earlier studies have reported that faecal $\mathrm{pH}$ is more alkaline in patients with colonic cancer, indicating a reduction in colonic carbohydrate fermentation to organic acids. The $\mathrm{pH}$ of faeces from 11 pre and 14 postoperative, selected colonic cancer patients without intestinal obstruction, major loss of appetite or weight, not treated with antibiotics, and without signs of dissemination or recurrence of the cancer, did not differ, however, from faecal pH in 17 patients with previous colonic adenomas removed by polypectomy and faecal $\mathrm{pH}$ in 17 age matched (mean 61 years) healthy controls (mean (SE) 7.03 (0.10), 7.15 (0.11), 7.20 (0.12), $7 \cdot 11(0 \cdot 12)$ respectively; $\mathrm{p}=0 \cdot 82)$. Faecal $\mathrm{pH}$ in 20 younger (mean 32 years) healthy controls tended to be lower $(6.89(0.07)$ compared with the older age matched control group $(p<0 \cdot 06)$.

Faecal concentrations of D-, $L$ - or total D+L-lactate did not differ between the patients with present or previous colonic cancer, adenomas, and the healthy controls (D+L-lactate mean (SE) 3.2 (0.5), 3.1 (0.3), 3.5 $(0.7), 4 \cdot 1(1.0) \mathrm{mmol} / \mathrm{l}$ respectively; $\mathrm{p}=0.72)$, and the production pattern of lactate from different carbohydrates (glucose and dietary fibre) in $16.6 \%$ faecal homogenates was similar in all the three groups of patients and the healthy controls.
\end{abstract}

Faecal pH was changed within days by modifications of the diet. An enteral diet free of fibre, starch, and lactose increased faecal $\mathrm{pH}$ within three days, whereas $\mathrm{pH}$ decreased when the colonic load of carbohydrates was increased by lactulose. Therefore, the reported alkaline faecal pH in patients with colonic cancer may reflect short term reductions in dietary intake and colonic fermentation secondary to the presence of the cancer, especially in patients with advanced disease, rather than long term differences in the precancer dietary habits.

(Gut 1993; 34: 625-629)

Epidemiological studies indicate that environmental factors influence the incidence of colorectal cancer and diet seems to be an important factor. ${ }^{1}$ The risk of colonic cancer seems to correlate with diets low in dietary fibre. ${ }^{23}$ Faecal $\mathrm{pH}$ is often below 6.5 in populations eating high fibre, low fat diets, whereas persons belonging to 'western societies' eating low fibre diets have a faecal $\mathrm{pH}$ above this value. ${ }^{+5}$ An alkaline faecal $\mathrm{pH}$ has been reported to be associated with a higher incidence of colonic cancer, ${ }^{6-9}$ suggesting that colonic neoplasia might be related to a reduction in the fermentation of dietary polysaccharides to organic acids in the large bowel.
Attention has mainly been focused on the formation of short chain fatty acids and the possible cancer protective role of butyrate. ${ }^{10-12}$ Faecal lactate is known to increase in patients with acidorrhea caused by saccharide malabsorption ${ }^{13}$ and in patients with active ulcerative colitis, ${ }^{14}$ but the concentration and production of lactate have not, to our knowledge, been investigated in patients with carcinoma of the large bowel.

The reported changes in faecal $\mathrm{pH}$ in patients with colonic cancer have now been widely accepted and quoted in many investigations and review reports on this subject. Changes in dietary and bowel habits may occur, however, as a result of the growing cancer in some of these patients. Efforts should therefore be made to differentiate between early changes in faecal $\mathrm{pH}$ occurring before the cancer has evolved, and short term changes secondary to loss of appetite, colonic obstruction, metastasis, etc, of no relevance for cancer pathogenesis.

Pre and postoperative patients were enrolled in this study as two separate groups, but patients were excluded if they had clinical signs of intestinal obstruction, major weight loss, loss of appetite, infections treated with antibiotics, or dissemination or recurrence of the cancer. Dietary habits of the selected patients were supposed to be unchanged and representative for the diet considered carcinogenic and harmful in the years before the cancer evolved. Because the adenoma-carcinoma sequence is accepted as the developmental pathway for most cases of colorectal cancer, ${ }^{15}$ a third group of patients with previous neoplastic adenomas was included. Faecal $\mathrm{pH}$ and lactate in the three groups of patients with removed adenomas and colonic cancers before and after surgery were then compared with healthy controls.

\section{Materials and methods}

\section{COLONIC CANCER AND ADENOMA PATIENTS}

The study population comprised 11 preoperative patients with present colonic cancer (seven men and four women, mean age 79, range 69-91 years), 14 postoperative patients with previous colonic cancer (six men and eight women, mean age 64, range 50-77 years, and 17 patients with previous colonic adenomas removed by colonoscopy (11 men and six women, mean age 66, range $49-87$ years) participated in the study. Seventeen healthy subjects with no history of gastrointestinal disease (eight men and nine women, mean age 61 , range $30-82$ years) served as controls.

The 11 patients with colonic cancer were selected as patients without complaints of appetite reduction or nausea, with a reported weight 
loss of less than $3 \mathrm{~kg}$, no clinical signs of ileus or subileus, no preoperative findings of liver metastasis, and in whom surgery was feasible and later accomplished (all as elective surgery). Faecal sampling was performed in 14 patients fulfilling the criteria, but cancer was not found in the removed colonic segment from three patients, who were therefore excluded from the study with new diagnoses of colonic adenoma (two) and diverticulitis (one). The remaining 11 cancers were located in the ascending (one), transverse (two), sigmoid (four), and rectal (four) segments of the colon, and were Duke A (three), Duke B (seven), and Duke C (one) adenocarcinomas. The 14 patients with previous colonic cancer had undergone right sided (seven) or left sided (two) hemicolectomy, or segmental sigmoid resection (five) because of adenocarcinoma of Duke A (two), Duke B (nine), and Duke C (three). None of the patients showed signs of recurrence at the time of faecal sampling, which was at least three months after surgery. Patients with colostomies were not included. The patients with previous adenomas had undergone colonoscopic polypectomy at least three months before faecal sampling with the removal of one or more neoplastic adenomas of more than $0.5 \mathrm{~cm}$ in size, which were either tubular (nine), tubulovillous (six), or villous (two). All adenomas found during colonoscopy were removed. All patients were enrolled consecutively and none of the patients had familial adenomatous polyposis or Gardner's syndrome. None had received chemotherapy or radiation therapy, and antibiotics were not given within two weeks before faecal sampling. No dietary' restrictions or recommendations were given. All subjects gave informed consent to participate in the study, which was approved by the local ethics committee.

DIETARY MODIFICATIONS IN HEALTHY SUBJECTS Twelve healthy persons (four men and eight women, mean age 32 , range 25-47 years) were given lactulose syrup $(0.66 \mathrm{~g} / \mathrm{ml})$ twice daily (Merck Chemical Co, Darmstadt, Germany) in doses of $80 \mathrm{~g} /$ day for three consecutive days. Stools were collected on the third day and used immediately for incubation experiments. Stools sampled before lactulose intake served as controls.

Thirteen healthy subjects (six men and seven women, mean age 31 , range $25-42$ years) were given Nutridrink (Nutricia, Zoetermeer, Hol-

TABLE I Concentrations of $L$-and D-lactate and $p H($ mean $(S E))$ in faeces from patients with colonic adenomas and cancers

\begin{tabular}{|c|c|c|c|c|}
\hline \multirow[b]{2}{*}{ Subjects $(n)$} & \multicolumn{3}{|l|}{$(\mathrm{mmol} / \mathrm{l})$} & \multirow[b]{2}{*}{$p H$} \\
\hline & $D+L$-lactate & $L$-lactate & $D$-lactate & \\
\hline $\begin{array}{l}\text { Controls (17) } \\
(95 \% \text { CIs) }\end{array}$ & $\begin{array}{l}4 \cdot 13(0 \cdot 95) \\
(2 \cdot 12-6 \cdot 14)\end{array}$ & $\begin{array}{l}2 \cdot 14(0 \cdot 44) \\
(1 \cdot 21-3 \cdot 07)\end{array}$ & $\begin{array}{l}2 \cdot 00(0.53) \\
(0 \cdot 88-3 \cdot 12)\end{array}$ & $\begin{array}{l}7 \cdot 11(0 \cdot 12) \\
(6 \cdot 86-7 \cdot 36)\end{array}$ \\
\hline $\begin{array}{l}\text { Adenomas }(17) \\
(95 \% \text { CIs })\end{array}$ & $\begin{array}{l}3.48(0.68) \\
(2.04-4.92)\end{array}$ & $\begin{array}{l}1 \cdot 56(0 \cdot 32) \\
(0 \cdot 88-2 \cdot 24)\end{array}$ & $\begin{array}{l}1 \cdot 92(0 \cdot 37) \\
(1 \cdot 14-2 \cdot 70)\end{array}$ & $\begin{array}{l}7 \cdot 20(0 \cdot 12) \\
(6 \cdot 95-7 \cdot 45)\end{array}$ \\
\hline $\begin{array}{l}\text { Cancer; before surgery (11) } \\
(95 \%) \text { CIs) }\end{array}$ & $\begin{array}{l}3 \cdot 20(0 \cdot 54) \\
(2 \cdot 00-4 \cdot 40)\end{array}$ & $\begin{array}{l}1.46(0 \cdot 26) \\
(0 \cdot 88-2 \cdot 04)\end{array}$ & $\begin{array}{l}1 \cdot 73(0 \cdot 29) \\
(1 \cdot 08-2 \cdot 38)\end{array}$ & $\begin{array}{l}7 \cdot 03(0 \cdot 10) \\
(6 \cdot 81-7 \cdot 25)\end{array}$ \\
\hline $\begin{array}{l}\text { Cancer; after surgery (14) } \\
(95 \% \text { CIs })\end{array}$ & $\begin{array}{l}3 \cdot 11(0 \cdot 31) \\
(2 \cdot 44-3 \cdot 78)\end{array}$ & $\begin{array}{l}1 \cdot 56(0 \cdot 20) \\
(1 \cdot 13-1 \cdot 99)\end{array}$ & $\begin{array}{l}1 \cdot 55(0 \cdot 21) \\
(1 \cdot 10-2 \cdot 00)\end{array}$ & $\begin{array}{l}7 \cdot 15(0 \cdot 11) \\
(6 \cdot 91-7 \cdot 39)\end{array}$ \\
\hline Anova & 0.72 & 0.47 & $0 \cdot 84$ & 0.82 \\
\hline
\end{tabular}

Anova $=$ one way analysis of variance $95 \% \mathrm{CIs}=95 \%$ confidence intervals. land) as the only caloric intake for three consecutive days with 24 hour faecal sampling on day three. Five of the subjects (three men and two women) had also participated in the lactulose study at least three months previously. The administered amount of Nutridrink (7500 $11500 \mathrm{~kJ} /$ day) was estimated from the body weight. Nutridrink contains $635 \mathrm{~kJ} / 100 \mathrm{ml}, 48 \%$ carbohydrates as maltodextrin and saccharose, $13 \%$ protein, $39 \%$ lipids, no starch or fibre, and only trace amounts of lactose. Fluid intake was free but restricted to non-sweetened tea, black coffee, or water. Control 24 hour faeces were sampled before the intake of Nutridrink was started.

\section{STARVATION OF RATS}

Forty male rats of the Sprague-Dawley strain with mean initial body weight of 238 (SE 5) g were used. They had free access to water and standard rat pellets (Altromin Werke, Lage, Germany). During the experiments the rats were taken off the stock diet and placed three in a cage without access to secreted urine and excrement. Ten animals were starved for $0,24,48$, or 72 hours, resulting in an average weight loss of 0 , 28,41 , and $49 \mathrm{~g}$ respectively. The animals were killed by a blow to the head and spinal dislocation. The colons were rapidly removed and caecal contents isolated and frozen for later analysis.

\section{PREPARATION AND ANALYSIS OF SAMPLES}

Freshly passed faeces were homogenised with five times their weight of isotonic solution (100 $\mathrm{mmol} / 1 \mathrm{NaCl} ; 50 \mathrm{mmol} / \mathrm{l} \mathrm{KCl}$ ) for study in an anaerobic faecal incubation system by the method of Vince et al. ${ }^{16}$ Several aliquots of $10 \mathrm{ml}$ from each faecal sample were simultaneously incubated in duplicate. Glucose, wheat bran, pectin, ispagula, or albumin were added at zero time in concentrations of $10 \mathrm{mg} / \mathrm{ml}$. Control incubations were faecal suspensions prepared with no addition of substrate. Incubation time was six hours at $37^{\circ} \mathrm{C}$, and termination was performed by freezing. Specimens were stored at $-18^{\circ} \mathrm{C}$ until analysis. The caecal contents of the rats were thawed and homogenised with five times their weight of distilled water before analysis.

L-lactate was measured by the spectrophotometric Boehringer L-lactate test, with L-lactate dehydrogenase. D-lactate was similarly measured by changing the enzyme to D-lactate dehydrogenase. L- and D-lactate dehydrogenase, $\mathrm{L}$ - and $\mathrm{D}$-lactate, and $\mathrm{NAD}^{+}$were obtained from Boehringer Mannheim Company, W Germany. Lactate concentrations were linearly proportional to the increase in $\mathrm{NADH}$ absorbance at $340 \mathrm{~nm}$ measured on an LKB Biochrom 4050 spectrophotometer (Pharmacia Biosystems, Copenhagen, Denmark). The $\mathrm{pH}$ of faeces was measured with a pH meter (Radiometer, Copenhagen, Denmark).

\section{STATISTICS}

Data were analysed by paired rank test or one way analysis of variance with an evaluation of the 
differences between individual groups by the test of least significant differences. ${ }^{17}$

\section{Results}

Table I shows lactate concentrations and $\mathrm{pH}$ in faeces from 17 normal subjects, 17 patients with previous colonic adenomas, 11 patients with colonic cancer before operation, and 14 colonic cancer patients after operation. Faecal concentrations of total $\mathrm{D}+\mathrm{L}$-lactate in patients who had colonic adenomas (mean (SE) 3.48 (0.68 mmol/l) and cancer before $(3.20(0.54) \mathrm{mmol} / \mathrm{l})$ and after surgery $(3 \cdot 11(0.31) \mathrm{mmol} / \mathrm{l})$ were not significantly different from concentrations in control subjects $(4.13(0.95) \mathrm{mmol} / \mathrm{l}) ; \mathrm{p}=0.72)$. The ratios of L-lactate in \% of total $\mathrm{D}+\mathrm{L}$-lactate in patients with colonic cancer before (mean (SE) $44 \%$ (2) and after surgery $(50 \%(5))$ and adenomas $(42 \%$ (3)) were of the same order as in normal subjects $(53 \%(3) ; p=0 \cdot 12)$. Neither did the molar concentrations of L- or D-lactate differ among the four groups. No differences in faecal $\mathrm{pH}$ were found between patients with colonic cancer before (mean (SE) 7.03 (0.10)) and after surgery $(7 \cdot 15(0 \cdot 11))$, patients with colonic adenomas $(7 \cdot 20(0 \cdot 12))$, and healthy controls $(7 \cdot 11$ $(0 \cdot 12) ; \mathrm{p}=0 \cdot 82$; Table I).

Table II gives the $\mathrm{D}$ - and L-lactate production in $16.6 \%$ faecal homogenates incubated for six hours with $10 \mathrm{mg} / \mathrm{ml}$ of glucose, wheat bran, pectin, ispagula, or albumin. The endogenous production of lactate in control homogenates with no additions of substrate was negligible and

TABLE II Production of $L$-and D-lactate (mean $(S E)$ ) in $16.6 \%$ faecal homogenates from patients with colonic adenomas and cancer ( $a$, before surgery; $b$, after surgery), incubated for six hours with glucose, wheat bran, pectin, ispagula, or albumin

\begin{tabular}{|c|c|c|c|c|c|}
\hline Substrate & Controls & Adenomas & Cancer & Cancer & $\begin{array}{l}\text { Anova } \\
(p \text { value })\end{array}$ \\
\hline & \multicolumn{4}{|c|}{$D+L$ lactate production } & \multirow[b]{2}{*}{$\begin{array}{l}0.97 \\
0.12 \\
0.83 \\
0.04 \\
0.69 \\
0.50\end{array}$} \\
\hline \multirow[t]{2}{*}{$\begin{array}{l}\text { None } \\
\text { Glucose } \\
\text { Wheat bran } \\
\text { Pectin } \\
\text { Ispagula } \\
\text { Albumin }\end{array}$} & $\begin{array}{c}-6(96) \\
4046(446) \\
218(43) \\
198(45) \\
15(15) \\
-3(15)\end{array}$ & $\begin{array}{c}-26(10) \\
2975(621) \\
306(100) \\
94(32)^{\star} \\
34(37) \\
-3(17)\end{array}$ & $\begin{array}{c}24(41) \\
3152(1157) \\
214(149) \\
45(18)^{\star} \\
-16(42) \\
-2(5)\end{array}$ & $\begin{array}{c}5(31) \\
2202(588) \\
275(68) \\
79(26)^{\star} \\
33(14) \\
-33(19)\end{array}$ & \\
\hline & \multicolumn{4}{|c|}{ L-lactate production } & \multirow[b]{2}{*}{$\begin{array}{l}0.98 \\
0.13 \\
0.85 \\
0.12 \\
0.27 \\
0.56\end{array}$} \\
\hline \multirow[t]{2}{*}{$\begin{array}{l}\text { None } \\
\text { Glucose } \\
\text { Wheat bran } \\
\text { Pectin } \\
\text { Ispagula } \\
\text { Albumin }\end{array}$} & $\begin{array}{c}1(48) \\
2056(208) \\
107(20) \\
89(22) \\
3(7) \\
-7(7)\end{array}$ & $\begin{array}{c}-10(5) \\
1629(376) \\
148(51) \\
48(17) \\
27(17) \\
6(10)\end{array}$ & $\begin{array}{c}12(20) \\
1722(660) \\
111(79) \\
18(11) \\
-10(19) \\
-4(4)\end{array}$ & $\begin{array}{c}1(16) \\
985(285) \\
140(34) \\
42(15) \\
19(6) \\
-5(6)\end{array}$ & \\
\hline & \multicolumn{4}{|c|}{ D-lactate production } & \multirow[b]{2}{*}{$\begin{array}{l}0.95 \\
0.13 \\
0.80 \\
0.02 \\
0.87 \\
0 \cdot 18\end{array}$} \\
\hline $\begin{array}{l}\text { None } \\
\text { Glucose } \\
\text { Wheat bran } \\
\text { Pectin } \\
\text { Ispagula } \\
\text { Albumin }\end{array}$ & $\begin{array}{c}-7(48) \\
1990(262) \\
112(24) \\
108(24) \\
13(9) \\
5(8)\end{array}$ & $\begin{array}{c}-15(7) \\
1346(259) \\
159(49) \\
47(16)^{\star} \\
7(19) \\
-9(9)\end{array}$ & $\begin{array}{c}12(21) \\
1431(514) \\
103(69) \\
27(7)^{\star} \\
-7(23) \\
1(2)\end{array}$ & $\begin{array}{c}4(16) \\
1036(313) \\
135(35) \\
37(13)^{\star} \\
14(9) \\
-28(15)\end{array}$ & \\
\hline \multicolumn{6}{|c|}{$\begin{array}{l}{ }^{\star} \mathrm{p}<0.05 ; \text { all values are } \mu \mathrm{mol} / \mathrm{l} \cdot \mathrm{h} ; \text { negative values }=\text { net consumption of lactate; production from } \\
\text { substrates is corrected for production in control homogenates. }\end{array}$} \\
\hline \multicolumn{6}{|c|}{$\begin{array}{l}\text { TABLE III Effect of colonic surgery on faecal } D+L \text {-lactate concentration, } p H \text {, and } \\
D+L \text {-lactate production (mean }(S E)) \text { from glucose in } 16 \cdot 6 \% \text { faecal homogenates }\end{array}$} \\
\hline \multicolumn{2}{|l|}{ Surgery } & \multicolumn{2}{|c|}{$\begin{array}{l}D+L \text {-lactate } \\
\text { concentration } \\
(\text { mmol/l) }\end{array}$} & & $\begin{array}{l}D+L \text {-lactate } \\
\text { production } \\
(\text { umol/l } \cdot h)\end{array}$ \\
\hline \multicolumn{2}{|c|}{$\begin{array}{l}\text { Sigmoid resection } \\
\text { Right sided hemicolectomy } \\
\text { Left sided hemicolectomy } \\
\text { Anova }\end{array}$} & \multicolumn{2}{|c|}{$\begin{array}{l}3.56(0 \cdot 75) \\
2 \cdot 61(0 \cdot 26) \\
3 \cdot 34(0 \cdot 25) \\
0.46\end{array}$} & $\begin{array}{l}\cdot 08) \\
\cdot .17) \\
0.06)\end{array}$ & $\begin{array}{l}2251(1038) \\
1103(934) \\
1857(100) \\
0.58\end{array}$ \\
\hline
\end{tabular}

often slightly negative, because initially present lactate was metabolised in many homogenates. By contrast, the addition of $10 \mathrm{mg} / \mathrm{ml}$ glucose caused a pronounced accumulation of both Dand L-lactate, which was significantly larger $(p<0.01)$ than six hour concentrations in assays with added wheat bran or pectin. The production of lactate was almost equally distributed between the L- and D-isomers. Lactate production from ispagula or albumin was negligible. The formation of lactate from glucose was significantly decreased in patients with previous colonic cancer when directly compared with healthy controls by an ordinary $t$ test $(\mathrm{p}<0.01)$, but differences between the groups were not significant when all four groups were compared with any of the three others by one way analysis of variance. The main finding was that the patterns of lactate production from different substrates were similar in all four groups, although a significantly decreased production of D-lactate from pectin in faeces from adenoma and cancer patients was registered. The final $\mathrm{pH}$ in homogenates after six hours of fermentation did not differ between the groups (not shown).

Table III shows the effect of bowel surgery on $\mathrm{pH}$, lactate concentration, and glucose induced six hour production of lactate. Differences associated with type of surgery - that is, sigmoid resections (five), right sided (seven) and left sided (two) hemicolectomies were not significant.

A modification of the diet of healthy young subjects towards a fibre, starch, and lactose free enteral nutrition based exclusively on the administration of Nutridrink, caused a significant rise in faecal $\mathrm{pH}$ from $6 \cdot 81(0 \cdot 09)$ to $7 \cdot 15(0 \cdot 13)$ $(p=0.025)$, whereas faecal lactate concentrations remained unchanged (Table IV). On the other hand, an increased load of carbohydrates, as lactulose, to the colon resulted in a pronounced decrease in faecal pH from $6.93(0 \cdot 10)$ to 5.94 $(0.25)(p=0.005)$, and a five to sevenfold increase in $\mathrm{D}$ - and L-lactate concentrations (Table IV). It was noticed that the faecal $\mathrm{pH}(7 \cdot 11$ $(0 \cdot 12)$ in the older age matched control group (mean age 61 years; Table I) was higher than the pH $(6.89(0.07) ; \mathrm{p}=0.056)$ in faeces sampled in the control period from the 20 younger healthy volunteers (mean age 32 years) who participated in the Nutridrink or lactulose study (five subjects participated in both studies, with a total number of 20 subjects).

The endogenous (with no substrate addition) or glucose stimulated production of lactate in faecal homogenates were not influenced by total enteral nutrition with Nutridrink (Table V). The intake of lactulose ( $80 \mathrm{~g} /$ day $)$, however, resulted in a pronounced increase in the endogenous L-lactate production comparable with production seen only after the addition of glucose to homogenates from subjects on an ordinary diet. The increase in $\mathrm{D}$-lactate production was of borderline significance $(p=0 \cdot 055$; Table V).

Table VI shows the $\mathrm{pH}$ and L- and D-lactate concentration in the caecal contents from fed and starved rats. Starvation for 24 hours increased $\mathrm{pH}$ by 1.5 units, corresponding to a more than 10-fold decreased caecal proton $\left(\mathbf{H}^{+}\right)$concentration, and was associated with a decrease in lactate concentration. Prolonged starvation for 48 and 
72 hours did not change the $\mathrm{pH}$ further and caused comparably small changes in lactate.

\section{Discussion}

Dietary fibre, resistant starch, and other saccharides escaping digestion in the small bowel are hydrolysed and converted to pyruvate and lactate by bacterial glycolysis. These intermediates are further converted to the short chain fatty acids, acetate, propionate, and butyrate..$^{18}$ Organic acids formed by fermentation may reduce caecal $\mathrm{pH}$ below 5-6, ${ }^{19} 20$ but colonic secretion of bicarbonate and other buffers increases $\mathrm{pH}$ in colonic contents during their distal passage along the large bowel, ${ }^{2021}$ and faecal $\mathrm{pH}$ is usually higher and changes less than $\mathrm{pH}$ in the proximal part of the colon. An excessive production of lactate is known to occur in the large bowel of some patients with short bowel syndrome, who malabsorb large amounts of saccharides into the colon. Colonic bacteria are able to produce both $\mathrm{L}$ - and D-lactate, by contrast with the intermediary metabolism of the human organism, which produces and degrades L-lactate only. D-lactate absorbed from the large bowel may therefore accumulate and cause acidosis. ${ }^{22-24}$ The addition of glucose to faecal homogenates (Tables II and

TABLE IV Concentrations of $L$-and D-lactate and $p H$ (mean $S E$ )) in faeces from 13 volunteers given fibre, starch, and lactose free enteral nutrition, and 12 volunteers given lactulose (80 g/day)

\begin{tabular}{|c|c|c|c|c|}
\hline & \multicolumn{3}{|l|}{$(\mathrm{mmol} / \mathrm{l})$} & \multirow[b]{2}{*}{$p H$} \\
\hline & $D+L$-lactate & $L$-lactate & $D$-lactate & \\
\hline $\begin{array}{l}\text { Controls } \\
\text { Enteral nutrition } \\
\text { p Value }\end{array}$ & $\begin{array}{l}3 \cdot 88(0 \cdot 38) \\
4 \cdot 64(0.64) \\
0 \cdot 29\end{array}$ & $\begin{array}{l}1.99(0 \cdot 21) \\
2 \cdot 18(0.31) \\
0.48\end{array}$ & $\begin{array}{l}1.89(0 \cdot 18) \\
2.45(0.40) \\
0.26\end{array}$ & $\begin{array}{l}6 \cdot 81(0.09) \\
7 \cdot 15(0.13) \\
0.03\end{array}$ \\
\hline $\begin{array}{l}\text { Controls } \\
\text { Lactulose } \\
\text { p Value }\end{array}$ & $\begin{array}{l}3.64(1 \cdot 35) \\
17 \cdot 22(4 \cdot 78) \\
0.005\end{array}$ & $\begin{array}{l}1.75(0.58) \\
9 \cdot 59(3 \cdot 26) \\
0.03\end{array}$ & $\begin{array}{l}1.89(0.95) \\
7.63(2.24) \\
0.01\end{array}$ & $\begin{array}{l}6.93(0.10) \\
5.94(0.25) \\
0.005\end{array}$ \\
\hline
\end{tabular}

p Value from rank test for paired samples.

TABLE V Production of $L$-and D-lactate (mean $(S E))$ in $16.6 \%$ faecal homogenates from 13 volunteers given fibre, starch, and lactose free enteral nutrition, and 12 volunteers given lactulose ( $80 \mathrm{~g} /$ day)

\begin{tabular}{lllll}
\hline Substrate & Controls & Enteral nutrition & Lactulose intake & p Value \\
\hline $\begin{array}{l}\text { Total D+L-lactate production: } \\
\quad \text { None }\end{array}$ & $-23(6)$ & $3(34)$ & - & 0.62 \\
$\quad \begin{array}{l}\text { Glucose } \\
\begin{array}{l}\text { L-lactate production: } \\
\quad \text { Glucose }\end{array}\end{array}$ & $3156(833)$ & $2197(821)$ & - & 0.50 \\
$\begin{array}{l}\text { D-lactate production: } \\
\quad \text { Glucose }\end{array}$ & $1856(509)$ & $1100(412)$ & - & 0.40 \\
$\begin{array}{l}\text { Total D+L-lactate production: } \\
\quad \text { None }\end{array}$ & $1300(340)$ & $1096(409)$ & - & 0.76 \\
$\begin{array}{l}\text { L-lactate production: } \\
\quad \text { None }\end{array}$ & $-22(15)$ & - & $2475(637)$ & 0.004 \\
$\begin{array}{l}\text { D-lactate production: } \\
\text { None }\end{array}$ & $-14(11)$ & - & $2395(612)$ & 0.004 \\
\hline
\end{tabular}

$\mathrm{p}$ Value from rank test for paired samples; all values are $\mu \mathrm{mol} / \mathrm{l} \cdot \mathrm{h}$.

TABLE VI Concentrations of $L$ - and D-lactate and $p H$ (mean $S E$ )) in caecal contents from fed and starved rats

\begin{tabular}{|c|c|c|c|c|}
\hline $\operatorname{Rats}(n=10)$ & $D+L$-lactate & $L$-lactate & $D$-lactate & $p H$ \\
\hline $\begin{array}{l}\text { Not starved } \\
\text { Starved } 24 \text { hours } \\
\text { Starved } 48 \text { hours } \\
\text { Starved } 72 \text { hours } \\
\text { Anova (p value) }\end{array}$ & $\begin{array}{l}6.90(0.64)^{\mathrm{a}} \\
1.45(0.18)^{\mathrm{h}} \\
1.40(0.14)^{\mathrm{h}} \\
0.83(0.08)^{\mathrm{h}} \\
<10^{-+}\end{array}$ & $\begin{array}{l}3.45(0.31)^{\mathrm{h}} \\
0.72(0.10)^{\mathrm{b}} \\
0.72(0.08)^{\mathrm{b}} \\
0.42(0.03)^{\mathrm{h}} \\
<10^{-4}\end{array}$ & $\begin{array}{l}3.45(0.33)^{\mathrm{h}} \\
0.73(0.09)^{\mathrm{h}} \\
0.69(0.07)^{\mathrm{h}} \\
0.41(0.05)^{\mathrm{h}} \\
<10^{-4}\end{array}$ & $\begin{array}{l}6.42(0 \cdot 10)^{4} \\
7 \cdot 94(0 \cdot 12)^{\mathrm{h}} \\
7.98(0 \cdot 12)^{\mathrm{h}} \\
7 \cdot 78(0 \cdot 11)^{\mathrm{h}} \\
<10^{4}\end{array}$ \\
\hline
\end{tabular}

Test of least significant difference, $\mathrm{p}<0.01$ : homogenous groups are marked with same superscript. All values are $\mathrm{mmol} / \mathrm{l}$.
V) parallels the in vivo conditions of D-lactate acidosis, and shows that simple and rapidly fermented saccharides, normally absorbed in the small intestine, may cause considerable lactate formation in the large bowel.

Low intake of dietary fibre reduces colonic fermentation, which also decreases in persons with an exceptionally efficient small intestinal starch absorption. ${ }^{25}$ Several investigators have found that $\mathrm{pH}$ in faeces from patients with colorectal cancer is increased compared with healthy controls. ${ }^{6-9}$ The percentage of unabsorbed (resistant) starch is less in patients with colonic adenomas that in control subjects, and it has been suggested that the resultant diminished carbohydrate fermentation promotes colonic neoplasia. ${ }^{26}$ It has also been argued that subjects deficient in lactase may benefit from the colonic production of organic acids from lactose. ${ }^{2}$

Dietary modifications in healthy subjects were associated with changes in faecal $\mathrm{pH}$. A decrease in the flow of carbohydrates into the colon obtained by the fibre, starch, and lactose free dietary formula (Nutridrink) was expected to decrease colonic organic acid formation and make the contents of the large bowel and faeces alkaline. The $\mathrm{pH}$ decreased, but the concentration and production of lactate remained unchanged (Table IV). Starvation reduces colonic carbohydrate fermentation and increases faecal $\mathrm{pH},{ }^{27}$ and starvation of the rats accordingly decreased caecal lactate and $\mathrm{H}^{+}$concentrations (Table VI). The reverse changes in $\mathrm{pH}$ were achieved by lactulose (Table IV), similar to earlier observations of the association between the intake of lactulose or dietary fibre and faecal $\mathrm{pH} .{ }^{4520}$

This study failed to show that faecal $\mathrm{pH}$ is increased in patients with colonic cancer (Table I). We suggest that this disagreement with the mentioned earlier work is related to the way patients were selected. Earlier studies probably included patients in whom surgery was impossible or not radical. The general food intake may have been diminished in several patients due to colonic stenosis, metastasis, loss of appetite, etc, causing a reduction in the amount of carbohydrates available for fermentation. Antibiotics may have been given to treat infections or as prophylaxis in relation to abdominal surgery, decreasing bacterial formation of organic acids ${ }^{28}$ and possibly increasing faecal $\mathrm{pH}$. Bacterial degradation of proteins to organic acids proceeds without lactate accumulation (Table II; incubations with albumin), and does not reduce colonic $\mathrm{pH}$ (not shown), ${ }^{29}$ because the organic acid production is buffered by the concomitantly formed ammonia. Therefore, degradation of proteins from a bleeding or secreting colonic cancer stabilises rather than decreases $\mathrm{pH}$, by contrast with the fermentation of saccharides in the healthy colon. Moreover, comparison of the two control groups indicated that younger people have a slightly more acidic faecal $\mathrm{pH}$ than older people, and patients with colonic cancers may therefore seem to have more alkaline $\mathrm{pH}$ when compared with younger controls.

Recently, Charalambides $e t a l^{30}$ found that faecal $\mathrm{pH}$ from sigmoid colostomies did not differ when five non-cancer trauma patients were 
compared with five patients who had undergone sigmoid colostomy for distal colonic cancer. Pye et $a l^{31}$ measured intestinal $\mathrm{pH}$ in 30 patients with colorectal cancer and 37 patients with colorectal adenomas with the elegant technique of a $\mathrm{pH}$ sensitive radiotelemetry capsule. These values were compared with those recorded in 66 normal subjects. No differences in intestinal $\mathrm{pH}$, including right, mid and left colonic $\mathrm{pH}$, were found, and they concluded that these results did not support the hypothesis that colonic $\mathrm{pH}$ plays a part in the aetiology of colorectal neoplasia. They did not explain why their results differed from earlier reports, but we believe that it is due to the fact that radiotelemetric measurements are possible only in cancer patients in a good condition that is, probably excluding acute patients with ileus or sepsis, vomiting patients, patients immediately after surgery, etc. Their patients therefore probably resembled our preoperative but electively chosen patients. Much research, including our own, has been initiated and based on the assumption that faecal $\mathrm{pH}$ in patients with colonic cancer is alkaline, and we think that it is important that the previous reports are balanced with the results of Pye et al, Charalambides et al, and ourselves.

Faecal $\mathrm{pH}$ is interpreted as a guidance for the kind of diet ingested in the years before the cancer evolves, but a change in diet can alter the faecal $\mathrm{pH}$ within days. Faecal $\mathrm{pH}$ measured in patients with colonic cancer, who are clinically unaffected by an early cancer or have regained health after surgery, may therefore be a more appropriate index for the half a century diet suspected of being carcinogenic, than faecal $\mathrm{pH}$ in non-selected patients. Another approach is to investigate patients with neoplastic adenomas believed to be in a precancer risk situation, but in agreement with previous investigations, ${ }^{89}$ faecal $\mathrm{pH}$ was not altered in patients with colonic adenomas (Table I). Therefore, the alkaline faecal $\mathrm{pH}$ in patients with colonic cancer may not be a primary event associated with the evolution of neoplasia. It is suggested that $\mathrm{pH}$ may increase as a result of short term changes in fermentation secondary to the progressive growth of a colorectal cancer. This work was supported by the Danish Cancer Society, the
Danish Medical Research Council, the Foundation of Jeppe Juhl Danish Medical Research Council, the Foundation of Jeppe Juhl
and his wife Ovita Juhl, the Foundation of Esper Boel, the and his wife Ovita Juhl, the Foundation of Esper Boel, the Foundation of Lundbeck, and the Danish Foundation for Advancement of Medical Science. The technical assistance of Jette
Christiansen, Bodil Petersen, and Anne Birgitte Larsen is greatly appreciated.

1 Doll R, Peto R. The cause of cancer. Quantitative estimates of avoidable risks of cancer in the United States today. $\mathrm{F}$ Natl Cancer Inst 1981; 66: 1191-308.

2 Thornton JR. High colonic $\mathrm{pH}$ promotes colorectal cancer. Lancet 1981; i: 1081-3.

3 Burkitt DP, Epidemiology of cancer of the colon and rectum. Cancer 1971;28: 3-13.
4 Walker ARP, Walker BF, Segal I. Faecal pH value and its modification by dietary means in South African black and white schoolchildren. S Afr Med F 1979; 55: 495-8.

5 Phillips RL. Role of life-style and dietary habits in risk of cancer among Seventh Day Adventists. Cancer Res 1975; 35: 3513-22.

6 Macdonald IA, Webb GR, Mahony DE. Fecal hydroxysteroid activities in vegetarian Seventh Day Adventists, control subjects and large bowel cancer patients. Am $\mathcal{F}$ Clin Nutr 1978; 31: S233-8.

7 Pietroiusti A, Caprilli R, Giuliano S, Vita S. Fecal pH in colorectal cancer. Ital f Gastroenterol 1985; 17: 88-91.

8 Vernia P, Ciarniaello P, Cittadini M, Lorenzotti A, Alessandrini A, Caprilli R. Stool pH and SCFA in colorectal cancer and polyps. Gastroenterology 1989; 96: A528.

9 Bech K, Kronborg O, Engel K, Kildeberg P. pH og aciditet i faeces ved kolorectal neoplasi. Ugeskr Lager 1990; 152 161-2.

10 Whitehead RH, Young GP, Bhathal PS. Effects of short chain fatty acids on a new human colon carcinoma cell line (LIM1215). Gut 1986; 27: 1457-63.

11 Gum JR, Kam WK, Byrd JC, Hicks JW, Sleisenger MH, Kim YS. Effects of sodium butyrate on human colonic adenocarcinoma cells. F Biol Chem 1987; 262: 1092-7.

12 Clausen MR, Bonnén H, Mortensen PB. Colonic fermentation of dietary fiber to short-chain fatty acids in patients with of dietary fiber to short-chain fatty acids in patients with 923-8.

13 Haemmerli UP, Kistler H, Ammann R, Marthaler T, Semenza G, Aurricchio S, Prader A. Acquired milk intolerance in the adult caused by lactose malabsorption due to a selective deficiency of intestinal lactase activity. Am F Med 1965; 38 7-30.

14 Vernia P, Caprilli R, Latella G, Barbetti F, Magliocca F Cittadini M. Fecal lactate and ulcerative colitis. Gastroenterology 1988; 95: 1564-8.

15 Morson BC. The polyp-cancer sequence in large bowel. Proc $R$ Soc Med 1974; 67: 451-7.

16 Vince A, Down PF, Murison J. Generation of ammonia from non-urea sources in a faecal incubation system. Clin Sci Mol Med 1976; 51: 313-22.

17 Armitag P'Statistical methods in medical research. London: Blackwell Scientific Publications, 1977; 4: 189-268.

18 Prins RA. Biochemical activities. In: Clarke RTJ, Bauchop T,

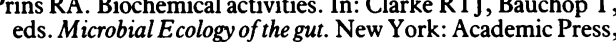
1977:83-183.

19 Thomsen LL, Tasman-Jones C, Lee SP, Robertson AM Dietary factors in the control of $\mathrm{pH}$ and volatile fatty acid production in the rat caecum. In: Kasper $\mathrm{H}$, Goebell $\mathrm{H}$, eds Colon and cancer. Lancaster: Falk Symposium, 1982:47-53.

20 Bown RL, Gibson JA, Sladen GE, Hicks B, Dawson AM. Effects of lactulose and other laxatives on ileal and colonic $\mathrm{pH}$ as measured by a radiotelemetry device. Gut 1974; 15 : 999-1004.

21 Cummings JH. Colonic absorption: the importance of shortchain fatty acids in man. Scand $\mathcal{F}$ Gastroenterol 1984; 93: chain

22 Oh MS, Phelps KR, Traube M, Barbosa-Saldivar JL, Boxhill C, Carroll H. D-lactic acidosis in a man with short bowel syndrome. N Engl F Med 1979; 301: 249-52.

23 Karton M, Rettmer RL, Lipkin E. Effect of parentera nutrition and enteral feeding on D-lactic acidosis in a patien with short bowel. FPEN 1987; 11: 586-9.

24 Stolberg L, Rolfe R, Gitlin N, Merritt J, Mann L, Linder J, Finegold S. D-lactic acidosis due to abnormal gut flora. NEnglf Med 1982; 306: 1344-8.

25 Englyst HN, Macfarlane GT. Breakdown or resistant and readily digestible starch by human gut bacteria. $\mathcal{F}$ Sci Food Agric 1986; 37: 699-706.

26 Thornton JR, Dryden A, Kelleher J, Losowsky MS. Superefficient starch absorption - a risk factor for Colonic neoplasia? Dig Dis Sci 1987; 32: 1088-91.

27 Illman RJ, Topping DL, Trimble RR. Effects of food restriction and starvation-refeeding on volatile fatty acid restriction and starvation-refeeding on volatile fatty a

28 Clausen MR, Bonnén H, Tvede M, Mortensen PB. Colonic fermentation to short-chain fatty acids is decreased in antibiotic-associated diarrhea. Gastroenterology 1991; 101 $1497-504$

29 Mortensen PB, Holtug K, Bonnén H, Clausen MR. The degradation of amino acids, proteins and blood to shortchain fatty acids in colon is prevented by lactulose. Gastroenterology 1990; 98: 353-60.

30 Charalambides D, Segal I. Colonic $\mathrm{pH}$ : a comparison between patients with colostomies due to trauma and colorectal cancer. Am $\mathcal{f}$ Gastroenterol 1992; 87: 74-8.

31 Pye G, Evans DF, Ledingham S, Hardcastle JD. Gastrointesti nal intraluminal $\mathrm{pH}$ in normal subjects and those with colorectal adenoma or carcinoma. Gut 1990; 31: 1355-7. 